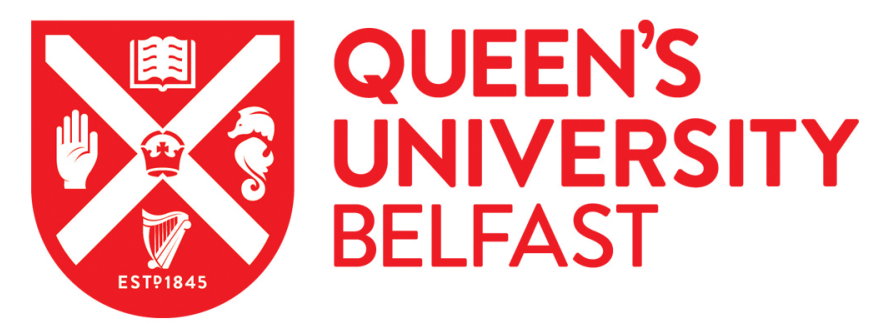

\title{
Transitional Optics: Exploring Liminal Spaces after Conflict
}

Murphy, J., \& McDowell, S. (2018). Transitional Optics: Exploring Liminal Spaces after Conflict. Urban Studies. https://doi.org/10.1177/0042098018788988

\author{
Published in: \\ Urban Studies
}

\section{Document Version:}

Peer reviewed version

Queen's University Belfast - Research Portal:

Link to publication record in Queen's University Belfast Research Portal

Publisher rights

(c) 2018 Urban Studies Journal Limited. This work is made available online in accordance with the publisher's policies. Please refer to any applicable terms of use of the publisher

\section{General rights}

Copyright for the publications made accessible via the Queen's University Belfast Research Portal is retained by the author(s) and / or other copyright owners and it is a condition of accessing these publications that users recognise and abide by the legal requirements associated with these rights.

Take down policy

The Research Portal is Queen's institutional repository that provides access to Queen's research output. Every effort has been made to ensure that content in the Research Portal does not infringe any person's rights, or applicable UK laws. If you discover content in the Research Portal that you believe breaches copyright or violates any law, please contact openaccess@qub.ac.uk. 


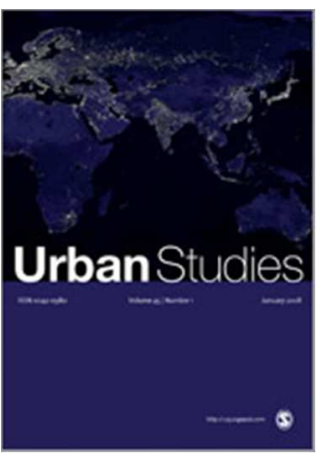

\section{Transitional Optics: Exploring Liminal Spaces after Conflict}

\begin{tabular}{|c|c|}
\hline Journal: & Urban Studies \\
\hline Manuscript ID & CUS-197-18-02.R1 \\
\hline Manuscript Type: & Article \\
\hline $\begin{array}{l}\text { <b>Discipline: Please select a } \\
\text { keyword from the following list } \\
\text { that best describes the } \\
\text { discipline used in your paper.: }\end{array}$ & Geography \\
\hline $\begin{array}{r}\text { World Region: Please select } \\
\text { the region(s) that best reflect } \\
\text { the focus of your paper. } \\
\text { Names of individual countries, } \\
\text { cities \& economic groupings } \\
\text { should appear in the title } \\
\text { where appropriate.: }\end{array}$ & Western Europe, Europe \\
\hline $\begin{array}{l}\text { Major Topic: Please identify up } \\
\text { to } 5 \text { topics that best identify } \\
\text { the subject of your article.: }\end{array}$ & Politics, Built Environment, Public Space, History/heritage/memory \\
\hline $\begin{array}{r}\text { You may add up to } 2 \text { further } \\
\text { relevant keywords of your } \\
\text { choosing below: }\end{array}$ & Liminality, Conflict \\
\hline
\end{tabular}

\section{SCHOLARONE \\ Manuscripts}




\title{
Transitional Optics: Exploring Liminal Spaces after Conflict
}

\begin{abstract}
The purpose of this article is to engage in a new conceptualisation of liminality, as it applies to space and place in societies emerging from conflict but not yet at peace. We adopt a case study approach of two urban environments: Derry/Londonderry, a city that experienced acute levels of violence during the Northern Ireland conflict, and Bilbao, the largest city in the Basque Country which has been at the crux of the cultural and economic struggle for Basque independence. The visual, built environment has been significantly reconfigured in both cities to communicate the transition from conflict. Yet the optics of peacebuilding does not necessarily reflect the experiences of communities as they move through complex processes. A more nuanced and critical reading of the urban environment often reveals stagnation within peace processes and the existence of liminal, inbetween spaces. This paper suggests that 'transitional optics' in societies moving out of conflict can physically illuminate the complex nature of building peace, and argues that the idea of permanent liminality can offer new ways of understanding the ways in which transitional processes can become trapped. An 'endpoint' is not always achievable, or perhaps for some, desirable. The characteristics of permanent liminality can be identified in three main areas: political imagery, physical regeneration and public space as a conflict arena.
\end{abstract}

\section{Keywords}

Politics, Built Environment, Public Space, History, Heritage, Memory, Liminality, Conflict 


\section{Introduction}

In societies emerging from violent conflict, the optics of 'peace' are often critically important in providing a framework for transition and soothing anxieties at a time of uncertainty. The aim of this article is to engage with the emerging conceptualisation of permanent liminality, as it applies to space and place in societies that are coming out of conflict but are not yet at peace. It does this by exploring 'transitional optics', visually manifested through the built environment of two case studies: Derry/Londonderry in Northern Ireland, a part of the UK (where the politics of nomenclature underscores continued division ${ }^{1}$ ), and Bilbao in the Basque region of Spain (where semantics and language speak to continuing conflict (see Gomez, 1998; Jack, 2015). We contend that these cities, and the societies in which they are situated, may be seen as liminal spaces - framed in the space between war and what comes after. Northern Ireland has since 1998 been engaged in a protracted period of volatile peacebuilding, while the Basque Country, which continues the grapple with the legacy of Franco, celebrated the disarmament of the militant organisation ETA, after seven years of a ceasefire in April 2017 (BBC News, 2017). Since the publication of Galtung's seminal work on negative and positive peace in 1967 , scholars have worked hard to deconstruct and extend conceptualisations of transitional processes and the spaces that emerge after war. Those researching the dynamics of transition and transformation in Northern Ireland, for instance, have pointed to the nuanced nature of peacebuilding. Shirlow (2008: 32), has written about progress in Belfast as 'a tale of two cities' with some communities locked in violence while others prosper, while O’Dowd and Komarova (2011: 48) have pointed to the persistent, rigid and deep-rooted political and cultural nature of 'territorial fixity and division' in many of the city's neighbourhoods despite significant urban regeneration. This is mirrored by Bollen's (2012) characterisation of the 'darkly present' conflict amidst regeneration and development in the Basque region. Framing peace processes as a continuum, subject to progression and regression, may convey the idea of an end point that perhaps is not always fully achievable, or for some, even desirable. We suggest that emerging conceptions of permanent liminality have the potential to provide a useful additional lens to enhance our understanding of this transitional space. In particular, we contend that an exploration of liminality allows us to develop understandings of the way in which conflict transformation can get 'stuck' and fail to progress, and how that 'inbetween-ness' can even be actively sought by conflict actors in an

\footnotetext{
${ }^{1}$ The city's name was originally named Doire (Derry) in the $6^{\text {th }}$ Century. It was changed to Londonderry in the 1600 s and the name continues to be a source of division.
} 


\section{Liminality, conflict and peacebuilding: The space inbetween}

Liminality is a concept which is of increasing interest to those engaged in work around transitional or emergent change in physical and social spaces. Deriving from the Latin for 'threshold', liminality conveys an equivocal, in-between state, which holds the possibility of, and conveys the journey to, a changed reality. A 'betwixt and between' space with altered 
rules and meanings (Turner, 1967), liminality is often marked by rituals, ceremonies and other forms of expression. Such places create openings for different thinking or give permission to try out new or alternative ways of interacting (Schirch, 2005). These 'rites of passage' that allow individuals to pass from one identity state to another (Van Gennep, 1960) are often conceived of as a processual process characterised by an initial stage of separation and detachment; a middle stage of liminality in which the subject or 'liminar' moves through a space that is different to both the 'before' and 'after' states; and a final stage of 'aggregation', or consummation of the liminal journey (Chreim, 2002). Soderlund and Borg (2017) suggest that there are three levels of liminality: individual liminal experiences, collective organisational processes and liminality as place or space. This type of scholarship on liminality which focuses on structures and organisations has a useful contribution to make in our understanding of conflict and conflict resolution processes. There is also a growing body of literature which explores, within different disciplinary contexts, the developing concept of 'permanent liminality'. Turner's (1969) assertion that certain environments can lead to an 'institutionalisation of liminality' has led to an additional body of work suggesting that liminality can gradually become a permanent state (Szakalczai, 2000; Thomassen, 2012; Johnsen and Sorensen, 2014). We contend, like Johnsen and Sorensen (2014), that conceptions of liminality have much to offer in environments where boundaries become blurred and that there is potential for these environments to 'reconfigure' the concept from a temporary one to the permanent one and towards Agamben's 'zone of indistinction' (1998).

Instabilities in social, political and organisational contexts, multiple meanings and the persistent nature of the liminal experience, all draw parallels with complex conflict transformation experiences. Reconceptualising liminality as a collective longitudinal experience of ambiguity and inbetween-ness within a changeful context, allows us to think of it less as a transition and more of a prolonged and potentially negative hiatus to an unknowable future. Extending this analysis allows us to conceive of the idea that such liminality may become a permanent state - with consequences for peace itself. This inherent paradox involves 'a fundamental suspension of ordinary social structures' and has been applied to contexts where overlaps in activities, identities and behaviours bleed from one sphere to another, and where clear delineations are no longer possible (Johnsen and Sørensen, 2015:322). Johnsen and Sørensen identify this in relation to modern work-life balance but it is, we suggest, equally applicable to societies where both peace and conflict seemly existing in overlap within the same spaces. This 'institutionalization', (Thomassen, 
2014) is a useful way to engage with liminality and its visual representations within our spatial cases, as well as an emerging recognition that liminality can be a collective as well as an individual experience (Czarniawska and Mazza, 2003). Identifying that liminal space may be a more permanent construction, with a 'continuous stress on transformation and transgression' (Thomassen 2012:160) also allows us to conceive of these spaces differently within the vicissitudes of peacebuilding.

To some extent this work from organisational studies mirrors significant scholarship around conceptual approaches to understanding the transitional undercurrents of a range of physical spaces, within conflict environments. For example, Boyer (1996:18) suggests that visual representations like architectural spaces give us an idea of the way that things 'could be'. They can become an 'anesthetized social world divorced from the realm of difference, diversity and antagonism' (Allen, 2006:442). For Weizman (2007: 13), architecture is a form of 'political plastic', something malleable that can be moulded to facilitate political aspirations or struggles. Allen (2006) writing about the power of public space and architecture, suggests that it offers 'something that is felt through the invitation to mingle, circulate and inhabit' (443). Yet the regeneration of public space in the cityscape can result in a 'contrived diversity rather than a real social mix' with a 'controlled policing of the public realm.' (Allen, 2006: 443). This leads to questions of what is really happening in public spaces that inhabit the transitional space between active conflict and sustained peace. Allen (2006) contends that the staging of spaces as promoting accessibility can often remain an illusion.

In order to think about the application of liminality to a reading of transitional space we must also look at our traditional conceptualisations of peace, conflict and contestation. We understand peace, like many others do (Koopman, 2011; McConnell et al, 2014; Ross, 2012), as something fluid, as a state of being that can change and evolve across time, place and scale. Political geographers have called for greater attention to be given to the nuances of building peace after conflict (Megoran, 2011; Koopman, 2017; Loyd, 2012). As Richmond (2014) and Brickhill (2015) observe, what looks like peace on one level (and to some actors), many look entirely different on another. In both Derry and Bilbao there has been distinct but concerted efforts to transform the built environment and convey a sense of successful transition. Yet this particular lens can conceal what Purdevkova (2017) calls the ongoing 'ontopolitical struggle' on the ground, over the terms and practices of restructuring a postconflict space. This struggle she observes 'encompasses the ways in which people act within 
the new spaces, asserting their interests not only by manoeuvring in physical space, but by appropriating the very logistics and languages that drive these initiatives' (2017: 537). We suggest that transitional optics are paradoxical, and if properly analysed can reveal pervasive tensions that resonate with this idea of permanent liminality.

\section{Liminal Spaces: Derry and Bilbao}

The city of Derry/Londonderry played a pivotal role in the Northern Ireland conflict. It was home to a vibrant civil rights movement in the 1960 s and the birth of the locally named 'Troubles' are attributed to a violent exchange between civil rights protesters and the police force which appeared to tip a society on tottering on the brink of violence over the edge in 1969 (Murtagh, 1999). With a history of economic and political discrimination the city suffered from high levels of deprivation and became a recruiting ground for Republican paramilitaries following the fatal shootings of 13 unarmed civilians in 1972 by members of the British Army (see Prince and Warner 2012; Conway 2003; Dawson 2005). The early years of the Troubles witnessed the formation of no-go areas for security forces as the city became increasingly polarised. Divided by the River Foyle running through its centre, the West Bank was predominantly Catholic (with one sizeable Protestant community living under the shadow of the infamous plantation walls) and the East Bank was predominantly Protestant. Until 1984 the city with a population of roughly 100,000 inhabitants were connected solely by one bridge - the Craigavon. The opening of the second bridge was a response to the swelling population and the pressure to alleviate traffic issues within the city.

As the conflict continued, the city was never far from violence. Its streets and buildings incurred the scars of shootings, riots and bombings, and its landscape grew increasingly militarised; from road blocks and burnt out cars acting as boundaries and policed by paramilitaries during the early 1970s, to the ever higher walls built around the Protestant enclave in the Fountain estate to alleviate inter-communal violence. The architecture of the Troubles was further reinforced by army checkpoints and watchtowers dispersed across the city to monitor a tense population. The birth of the peace process ushered in a new period for the city and its geography began to evolve. Normalisation began slowly, but gained currency following the 1998 Belfast Agreement and the gradual withdrawal of the British Army. The military base at Ebrington on the East Bank was transferred to the public as part of the Chancellor's Reinvestment and Reform Initiative in 2003 to transform sites of conflict into 

reimagining of what the city could become. The mammoth task of turning Ebrington, a site associated with the military since the 17th Century, into an open, shared and deterritorialised space was undertaken by the Ilex committee who began working on a blueprint for the site (see Hocking, 2015). The idea for a footbridge to connect the city's population had been discussed for many years but was given weight by this new development opportunity. The footbridge, named the 'Peace bridge' was not only a symbolic entity, but one practically designed to enhance the mobility of the city's inhabitants by opening up the largely segregated city. In June 2011, the new bridge opened, (see Selim, 2015) and in 2013 the city embarked upon a year of celebrations as the first UK City of Culture. This year of celebrations were perceived to be a seminal moment for the city, the culmination of an arduous journey from a violent past. As Culture, as Boland et al, (2015) suggests was to be 'valorised' to finally consolidate an elusive peaceful future. McDermott et al, (2015: 623) argue that the initiative did have a number of successes: 'Whatever the original intention, the city did succeed in initiating its 'new story'; one that radically, if only temporarily, reframed its inhabitants in a revised geographical context with a common heritage and a shared future'. Bilbao is a port city and capital of the Basque Vizcaya province in northern Spain. For de Cerro Santamaría (2011:91) it is the place where the "urban phenomenon of Basque nationalism' was born. As the largest city in the Basque country, it is known for its spectacular Guggenheim museum (designed by Frank Gehry and opened in 1997) and as a key location of the Basque conflict and the actions of the extreme nationalist grouping ETA. Bilbao's history reflects similar themes to many areas in the region, centring on the birth of modern Spain and the conflicting nationalist and ideological iterations of its development (Vacario and Martinez Monje, 2003). The devastation of the Spanish Civil War, including the destruction of the city's bridges was followed by an economic revival, especially of the iron industry and a significant growth of population. However, this influx of new workers also contributed to an environment where Basque and Spanish nationalisms clashed fiercely (Rice, 2013; Woodworth, 2001; Jack, 2015). Violence and calls for independence continued following the death of Franco and the Spanish transition to a constitutional monarchy in 1979. While the Basque country achieved extensive autonomy, a campaign for independence and ongoing political conflict became more significant. Meanwhile, the underlying industrial strength of the city was hit hard by the worldwide crisis in the iron and steel industry, and 
dealt a further blow with the closure of the famous Euskalduna shipyards. The economic restructuring that followed, including a shift from an industrial to a service based economy saw significant urban and spatial regeneration. The creation of Bilbao Ria 2000 (Bollens 2012) and latterly Bilbao Metropoli-30 have played important roles in engaging local stakeholders in developmental initiatives. The emblem of this 'New Bilbao' is the Guggenheim, but in tandem to the iconic building is the regeneration of the historic centre, the creation of the metro and the clean-up and recovery of the estuary waters and the new bridges. For Bilbao, they were an attempt to outwardly create a trajectory away from both a failed industrial heritage and the conflict of the past. However, even the Guggenheim is not untainted with the conflict. In the week before its inauguration a number of attacks attempted to disrupt the official opening ceremony including the murder a policeman who died of gunshot wounds after challenging two men unloading plant pots outside the entrance. Urban regeneration has taken place against a backdrop of tense Basque politics and until recently, an ongoing ETA campaign of violence (alongside equally long-running efforts to create peace). The ETA process of disarmament with international verifiers that began in February 2014, and the announcement of a move towards dissolution in the summer of 2014 were significant junctures in the conflict resolution process. While ETA has announced a dissolution, the dispute between Basque nationalism and the central Spanish state continues to manifest itself in the frequent large and small prisoner protests. The message is visually reinforced by the 'Etxera' signs (meaning back home) that festoon streets and apartment buildings throughout the city. They are matched by other signs and graffiti around the iconic buildings and the revived waterways of the old city 'Not French, Not Spanish, but Basque'.

\section{Methodological approach}

The theoretical framework informing this study seeks to explore the liminal nature of space in societies in transition from conflict. The conceptualisation of these cities as liminal spaces was an emergent one, resulting from a number of similar broadly-based studies of conflict, change and space over a seven-year period. While the struggle for Basque independence and the struggle for Irish unification have often looked to and referenced each other (see Alonso 2004), Derry and Bilbao are two very different cities and engaged in divergent processes of transition. The built environment also differs. The constructed environment of peacebuilding is juxtaposed with the physicality of segregation and continuing division. Derry's new 
'spaces' (see Doak, 2014) coexist alongside the continued trappings of sectarianism and division-of peace lines, barriers, murals and flags. Bilbao is emerging from a dissimilar conflict and its built environment has been at the fore of a radical separatist and culturally transformative politics that sets the region apart from Spain (Jack, 2015). Yet both cities continue to grapple with how best to deal with the past and have engaged with each other during times of active violence (see Sanchez-Cuenca, 2007) and peacebuilding (see Espiuo Idiago, 2015). In spatial terms, the reimagining of both Derry and Bilbao has centred around the development and regeneration of two iconic bridges which have contributed to the place identity of these 'post-conflict' cities (Bollens, 2012). Our research encompassed three main methods of data collection - interviews, witness seminars ${ }^{2}$ and two day residential workshops with a range of participants. Workshops were location-based and participative in that they involved an opportunity to visit urban spaces in order to capture significant images of the environment, and to discuss these images within the workshops. Methodological approaches which included walking through (sometimes alongside participants) and observing specific places are practices that are gaining increasing currency (see Evans \& James, 2011; Mitchell and Kelly, 2011). Data was initially analysed and coded to explore institutional change, management of contested spaces and the development of commemorative communities after conflict. As the liminal nature of these environments emerged as a finding, the data was recoded to explore transitional space in both locations. The three themes dealt with in this paper emerged from that coding process and were common to both cities. For example, the theme that came to be tagged 'political imagery' contained recurring sub codes such as 'graffiti', 'murals' 'flags' 'emblems' and 'posters'. The 'physical regeneration' theme included subcodes such as 'public space', 'bridges' 'art' and the 'ongoing' protest theme contained recurring concerns around 'protests' 'parades' and 'living with the past'. Those who engaged with the research included community workers, managers responsible for the maintenance and development of urban and spared spaces, those engaged in urban and economic regeneration, and those active politically in both contexts.

\footnotetext{
${ }^{2}$ Witness seminars, developed as a technique to facilitate the creation of material or insights from recent history, allow for the exploration and focused discussion on complex areas of concern, pivotal moments, and controversial events see for example J Coakley and J. Todd, 'Breaking Patterns of Conflict in Northern Ireland: New Perspectives', Irish Political Studies, 29/1 (2014), 1-14..
} 
Participation in data collection was secured through a process of snowball referral and the use of existing research networks (Saunders and Townsend, 2016). Individuals were invited to participate and suggest additional invitees from a range of public private and third sector organisations in both Derry and Bilbao. Interviews were semi-structured and focused on institutional and community change after conflict. The four witness seminars were arranged in neutral venues ${ }^{3}$, in both locations with experienced researchers who had previous familiarity with conflict environments and explored issues of shared space, visual manifestations of the past and attempts to frame the future. The witness seminar format lends itself to discussions on particular issues or topics and the seminars were facilitated on that basis with key topics such as 'regeneration', 'the past' 'public commemoration' and 'the future'. All aspects of the data collection adhered to strict ethical guidelines in relation to participant's anonymity, data management and storage. The facilitators had contact with participants beforehand to ensure that the research questions themselves did not raise or provoke difficulty or distress among the participants (Svorenčík \& Maas, 2015).

The remainder of the paper will explore the three key themes that emerged from the data collection and subsequent process of analysis that each speak to this idea of permanent liminality: public imagery as a persistent conflict identifier; significant strategic attempts at spatial, including architectural, alteration as conscious post conflict 'framing; and, finally, the ongoing use of public spaces as interfaces of protest and unrest.

\section{Political imagery as a tenacious conflict identifier}

One of the most interesting spatial characteristics of these two liminal cities is the way in which political imagery represents tenacious or persistent conflict. This imagery is diverse, from commemorative monuments with their emotive language (as one witness seminar participant put it 'commemoration tends to assign blame'- Derry 2015) to murals, flags, emblems and political graffiti. Language such as 'killed by' or 'murdered by' is particularly pertinent in the commemorative streetscape of Derry which has a saturation of monuments, plaques and commemorative murals. Here we see a competition for hegemonic victimhood in the wake of armed violence and a struggle to legitimate violence or attribute blame (see

\footnotetext{
${ }^{3}$ In a place without active association to the conflict, or affiliation to a particular political group.
} 
McDowell and Switzer, 2010). In the neighbourhood of the Bogside, political imagery suggests a dynamic conflict which has not necessarily ended. In addition to the murals and monuments, political posters continue to call for justice and historical inquiries into crimes committed throughout the Northern Ireland Troubles. Language as a conflict signifier is also evident in Bilbao and perceived by many as a symbol of the continuing separatist conflict. A witness seminar participant in Bilbao observed: 'We've got symbols that are still difficult here. One for example are our languages... the use of the Basque language in our case, has been a barrier the way some people perceive and treat the Basque language and has been a barrier to how some people treat peaceful coexistence'. A participant in Derry made a similar comment 'inside the walls everyone calls the city 'Derry'-outside the walls the choice between 'Derry', 'Londonderry', or 'Derry/Londonderry' is used to mark out politics and identity'. In these instances, we see language posited as a symbol of continued division, as an expression not just of communication, but as a cultural and political tool to further perpetuate and sustain conflict.

In both environments there has been a great deal of work to, as one participant in Derry put it, 'take the heat out of cultural expressions', however the dichotomy of a city's public and private face still looms large. Other participants talked about the reality of dissident Republican paraphernalia resurfacing, both privately and in public spaces, in the form of graffiti and flags. Dissident Republicanism takes many forms in Northern Ireland but is largely used to describe those who did not support the 1998 Belfast/Good Friday Agreement and still hope to achieve a united Ireland. Dissidents who advocate using armed violence, despite the absence of a significant mandate (see Tonge, 2012), remain a persistent threat to the peace process (see Frampton, 2012). Dissidents in Derry have used the streetscape to document their aspirations and to refute the hegemony of 'mainstream' Republicanism which they believe has 'sold out' by accepting a power-sharing government in Northern Ireland. The framing of graffiti as an expression of conflict is well-documented. Waldner and Dobratz (2013: 377) view the practice as an 'expressive resistance tactic' that challenges power relations. Aimed at a specific audience, graffiti articulates a particular discourse or political motivation (Kan, 2001). Hanauer's (2011) analysis of political graffiti on the separation barrier in Abu Dis in Israel/Palestine points to its discursive function. It, he argues, strives to directly influence macro-scale politics by raising awareness of the political situation in Palestine. Bush writing in 2013, suggested that political graffiti was 'curiously absent' from the urban landscapes of Northern Ireland. We would argue that it has, in fact, become much 
more prominent, as dissident Republican subculture makes its mark on the streetscape of Derry- and has become more acute since the death of the former Deputy First Minister Martin McGuinness, in February 2016. McGuinness was a former member of the paramilitary group, the Irish Republican Army before becoming a key player in its political wing Sinn Féin. Before his death, McGuinness symbolised mainstream Republicanism. Dissident Republicans launched an audacious commemorative campaign between April and May 2016 (The Irish News $17^{\text {th }}$ April 2017). This campaign has had a profound visible presence in the landscape with a plethora of graffiti, flags, pictures of guns and slogans erected in residential communities around the city which had previously very little territorial trappings. Furthermore a campaign to free a Republican prisoner has resulted in recurrent graffiti in public places since 2016 calling for an end to British internment. The 'internment' of prisoners 'of war' in a 'post-conflict' context is significant and has important implications for the process of transitioning. Individuals imprisoned either for allegedly continuing to engage in paramilitary activity in particular spaces is indicative of broader problems within peacebuilding. Bush (2013: 167) sees graffiti as 'a spatialized form of political communication' which offers an insight into 'competing authority structures within the contested, fluid, and volatile urban environments of both war zones, and non-war zones'. This visible iconography of resistance perhaps illustrates a hardening of attitudes within some communities, and of resistance to the notion that peacebuilding is a linear process.

The omnipresent spectacle in Bilbao of both peace flags and 'Etxera' signs (literal meaning bring them back home) with reference to prisoners, and the visible tensions of an unresolved conflict over identity ('Not French, not Spanish, but Basque' - displayed in English for tourist consumption) and place (Bilbao or Bilbo) illustrates the unsettled nature of the region and the ever present nature of contestation. Here again we see the lingering issue of prisoners and ongoing struggle with the wider state structure. Street banners proclaiming political messages, allegiance and the referencing ongoing disputes, individual prisoners and the legacy of past violence are impossible to miss. The counter violence message of ;Basta Ya! (Enough is enough!) and the bright yellow peace signs festooning private apartments all speak to an ongoing dialectic of both past violence and present day progress.

\section{Physical regeneration as a post conflict framing}


The conscious 'reframing' (Kaufman et al, 2003) of the two case study cities spatially and sometimes architecturally, was a significant theme of interest within the data. For Mitchell and Kelly (2011:307) the regeneration of space in capital cities or places synonymous with violence following a period of armed conflict can become the 'physical embodiment of peaceful places'. Yet they suggest such places are often the result of uneven processes. Governments and developers alike have often used architecture to intervene in conflict. In Northern Ireland, the Chancellor's 2003 Reinvestment and Reform Initiative sought to transfer the ownership of former military sites to the public as part of its commitment to normalisation through demilitarisation. Each site, the initiative stated, must act as a beacon for peace and generate economic income or represent socio-economic value (see Graham and McDowell, 2007). The symbolism of this initiative was hugely significant. Using regeneration to underpin the peace process has been a key strategy for policymakers and developers seeking to consolidate a volatile political climate (see Neill, 2006 Large architecturally iconic projects such as the much vaulted Guggenheim in Bilbao and the 'peace' bridge in Derry are conscious attempts at political, social and cultural reimagining. The aesthetics of peacebuilding play an important role in underpinning transitional societies. Gonzalez (2010: 2) discussing policymakers 'fascination' with the urban environment of Bilbao, refers to the city as a 'phoenix that has emerged from a crisis'. Its economic regeneration coupled with its architectural reimaging has captured the imagination of those tasked with mimicking its success in other places. Other reshaping projects like the Bilbao metro and the reimagining of some public spaces in Derry, have created opportunities for the public to move more freely through what were once more contested or less cohesive neighbourhoods within the urban landscape. This alteration was noted by a research participant in Derry: 'the map shows a pathway between bridge and memorial as a shared space', illustrating a recognition that positive changes have been made and could be built on. For many participants, Derry is still a 'city of contrasts'. They cited empty houses with fake frontage representing a 'quick fix attitude' embodied within the ethos of the 'City of Culture' and a desire to 'make the city look good superficially'. Some participants noted that architectural interventions since cessation of violence were 'limited to key public and commercial spaces'. Measuring the success of built interventions imagined to consolidate peace is intrinsically complex. Rybcynski (2002) suggests that the 'Bilbao effect' created by Frank Gehry's 'iconoclastical' Guggenheim has been profound shaping not only what we come to expect from museums but also radically informing architectural practice. For Rybcynski (2002: 23) 'great architecture carries many messages about society and 
individuals, about our values and our dreams'. The architecture in both cities has been praised for its' symbolic importance' but as our research suggests, this is not always felt equally across communities. The participants in witness seminars in both locations talked about the continuing tensions embedded within a divided and contested past and the challenge of moving forwards. One participant from Derry, a community worker from an interface area in the city, talked about the importance of commemorating the past in communities that had experienced some of the worst violence in the city. He suggested there was a common feeling of 'We're never going to forget what you did to us. And we're never going to allow you to forget it either'. This was underpinned by concern over the continuing levels of segregation in the city, symbolised by the many 'peacewalls'. A victims group member present noted 'walls have a double meaning - both to protect those within and exclude those without - they function very clearly as symbols, offering or denying a welcome'. Another talked about concerns when looking through or over walls, 'what I am thinking of [is] the other person - are they a threat or a friend?'. Another commented on the anxiety associated with entering certain spaces 'I was struck by what you said about the fear of the unknown, I was thinking about the fear of going into 'other' spaces'.

Similar concerns were echoed in Bilbao. One research participant actively engaged in economic development spoke about the importance of the Guggenheim as a loci for change: 'We want to get rid of this stigma of terrorism - to introduce ourselves better to the world' and another spoke about the importance of the metro as a unifying mechanism within the city in general 'opening up' previously less accessible neighbourhoods and pulling together the diverse urban landscape. This participant also made reference to the abundance of public art and the need to pull together both disparate neighbourhoods and political perspectives. However, these spaces and connective devices also become imbued with the reality of conflict. A memorial in the Guggenheim is a reminder of the violence that marked its opening. As public art was being erected throughout the city, ETA remained commitment to its political objectives. The regeneration of Bilbao was perceived by many research participants as a deliberate attempt to change the conversation. The optics of peace and prosperity, while maintaining a distinct sense of Basque identity, was vitally important. The journey from an 'old and dirty city' plagued by conflict to a new streetscape symbolic of a peaceful and dynamic Basque future. Participants mentioned the deliberate use of colour 'Bilbao blue' as a cultural leitmotif and the complex inter dynamic between regeneration and peace in the region. Ongoing disputes about historic street names in Bilbao and the Basque 
country more widely dating back to the Franco regime illustrate an ongoing concern and a struggle which goes beyond the present day Basque conflict. The ongoing dispute with Spain in terms of the nature of the conflict has also impacted upon the ability to physically 'reframe'. As on Basque workshop participant commented 'there is no Spanish application to EU for help and support. There is meant to be no conflict, so there is no peace process'. As de Cerro Santmaría (2011) suggests these overarching 'globalisation discourses' have long been understood by Basque nationalists as a tool through which to articulate a nationalist agenda that seeks sovereignty as the end goal.

\section{Public spaces as political arenas of ongoing protest}

Of all the themes that arose within the research, the continued and sometimes increased use of public spaces as ongoing areas of political protest was the most compelling. In Derry for example, participants spoke about the 'politicisation of the landscape' and the impact that it had on generations of children. It was not just conflict in the past that was an issue in both contexts. Representatives of prisoner groups in Bilbao who were instrumental in staging large regular protests and marches spoke of the daily engagement in a conflict issue which isn't close to resolution, and in Derry those working with former members of the British security forces articulated the omnipresent threat to families of security forces from dissident Republicans. Protests against inclusive remembering outside the Free Derry Museum, a community museum which was first established to narrate the Bogside's community experience of violence in the city, saw public space once against as imbued with elements of the past in the present. The museum came under fire in August 2017 for including the names of British soldiers who had died in the community throughout the Troubles on an exhibit. Siblings of some of the civilians killed by the Army on Bloody Sunday staged a six-day protest until the decision was taken to remove the exhibit. Jeanette Harkin (BBC News, 2017), a member of the Bloody Sunday Trust who also lost a sibling in 1972 said 'I regret that there's so much hurt in the community but that we can't recognise that hurt in other areas'. The furore over the decision to move away from partisan remembering is indicative of the controversy wrapped around healing and moving on.

The series of protests orchestrated by Republicans in Derry against the imprisonment of political prisoners have often intersected with global separatist campaigns. In October 2017, Republicans orchestrated a large protest in a busy traffic junction in the Bogside in support of 
Catalonia's referendum on independence. The protest also called for the immediate release of Republicans allegedly interned in Northern Ireland's prisons. In Bilbao, research participants spoke of the distance relatives had to travel to visit ETA prisoners distributed through Spanish prisons. This was often juxtaposed with an acknowledgment that the shadow of the Civil War still loomed large and that the recovery and memorialisation of mass graves and victims remains was an ongoing process. Participants recalled the recent construction of a public memorial or columbarium ${ }^{4}$ for those murdered during the civil war and whose unidentified bodies have been recently recovered as an unsettling but foundational experience, now reflected permanently in the landscape.

In addition to marches supporting amnesty for political prisoners, and the relocation of prisoners held in Spanish jails, street protests reflect wider debates such as support for the Basque language and parallel independence movements such as those in Catalonia. One witness seminar member reflected 'the narrative is the real war', while others recalled the kidnap and murder of Miguel Angel Blanco as a demarcation in both the peace process and the use of public space: 'Miguel Angel Blanco was like a landmark. There was a before and an after.... The social reaction to that event was totally different to what we have seen in the past. The streets were taken in a different way'. For many participants, the outrage and shock evoked by the murder of Blanco brought peace protestors onto the streets for the first time, despite concerns about intimidation and disloyalty. This opened up these spaces to be both a location for division and for a coming together.

\section{Conclusion: Liminality, Space and Transitional Optics}

The sections above discuss visual illustrations of liminal space in societies moving from conflict but not yet settled into a peaceful environment. Political imagery, physical regeneration and space as a conflict arena are all optical manifestations of the liminal nature of conflict transitions. Neither fully at peace nor fully at war, both cities are conscious of their 'inbetween-ness', of the changed rules around interactions, and of the unanticipated realities of the present situation. The liminal state for both cities is prolonged and propped up on either end by an unresolved past and an as yet unknowable, unstable future.

\footnotetext{
${ }^{4}$ A place for the respectful and often public storage of cinerary urns.
} 

Johnsen and Sørensen (2012) who regard liminality less as a provisional, processual stage on a journey and more as a space where activities, characteristics and actions have overlapped and clear distinctions between the present and the past are not possible. This institutionalization of liminality, (e.g. Szakolczai, 2000; Thomassen, 2012) allows us to configure our understanding of liminal space as a more permanent construction, with a 'continuous stress on transformation and transgression' (Thomassen, 2012, p.160). We see this as a collective, nuanced experience with communities aware of their 'betweeness' and striving to move into a new environment, but understanding that underlying currents hold them in liminal space. Transitional optics in Derry convey a sometimes faltering, sometimes progressing peace process and illustrate the resilience of Dissident Republicans at street level. These underlying tensions and their visual representations draw our attention to what is often otherwise a less obviously conflicted space. Bilbao is a city which has actively tried to haul itself into liminal space as a conscious act. Again, both popular protests and visual demonstrations of identity and contestation surface despite the iconic beauty of the Guggenheim and the connective physicality of the metro and bridges. Prisoners, protests, the past and present identities continue to overlay cultural reimagining. For both these cities building peace is a long term endeavour and stalled transition is all around. Drawing attention to the liminal nature of these processes allows us to understand more about the outworking's of urban environments as they emerge from active conflicts and to identify both the paths and blockages to a peaceful future that liminality represents.

This paper makes a number of new contributions. Firstly, it extends the concept of liminality into literature around transitions from conflict, and particularly around the spatial and physical manifestations within urban contexts. Secondly, it identifies manifestations of the liminal nature of these public spaces in two cities - Derry and Bilbao and identifies three characteristics of liminality within the cases. These characteristics or 'transitional optics' as we have termed them, are identified as the existence of persistent political or conflict imagery; physical regeneration as a conscious act of framing away from past identification with violence; and the continued utilisation of public space as a conflict arena. We see these manifested in both cities. Visual markings like graffiti and slogans, physical improvement and regeneration of significant public arenas, and ongoing parades, protests and demonstrations all operate to entrap conflict transformational initiatives in liminal space. A recognition of the optical manifestation of liminality allows us to better understand and 
recognise liminal spaces in societies engaged in the difficult and complex transition from contestation. Thirdly, the paper reflects on how notions of liminality can allow us another lens to explore the complexity of change and its impact on space and place. In particular, we explore the associated, developing construct of permanent liminality and link it to peacebuilding within an urban context. We argue that recognising that there is a possibility that liminality can be reconfigured as a potentially permanent state gives us another tool with which to refine our understanding of conflict transformation processes which are necessarily complex and multifaceted. Framing liminality as a potentially permanent facet of urban peacebuilding has the potential to facilitate a more nuanced understanding of spatial and visual manifestations of the environment between war and what comes after. 
Bollens SA (2012) City and Soul in Divided Societies. London: Routledge.

Boyer MC (1996) The City of Collective Memory: Its Historical Imagery and Architectural Entertainments. MIT Press.

Brickell K (2015) Towards intimate geographies of peace? Local reconciliation of domestic violence in Cambodia. Transactions: Institute of British Geography 40: 321-333.

Bush K (2013) The politics of post-conflict space: the mysterious case of missing graffiti in 'posttroubles' Northern Ireland. Contemporary Politics 19(2): 167-189.

Coakley, J. and Todd, J. (2014) Breaking Patterns of Conflict in Northern Ireland: New Perspectives. Irish Political Studies 29 (1): 1-14.

Coulter, C. \& Murray, M. (2008), Northern Ireland After the Troubles. Manchester University Press, Manchester.

Conway U (2003) Active remembering, selective forgetting, and collective identity: The case of Bloody Sunday. Identity: An International Journal of Theory and Research 3: 305-323. 
Chreim S (2002) The Continuity-Change Duality in Narrative Texts of Organizational Identity. Journal of Management Studies 42: 567-593.

Czarniawska B and Mazza C (2003) Consulting as a liminal space. Human Relations 56: 267-290.

Dawson G (2005) Trauma, Place and the Politics of Memory: Bloody Sunday, Derry 1972-2004. History Workshop Journal 59: 151-178.

De Cerro Santamaria G (2011) In: Davis DE and de Duren NL (eds) Cities and sovereignty: identity politics in urban spaces. Indiana University Press.

Doak P (2014) Beyond Derry or Londonderry: Towards a framework for understanding the emerging spatial contradictions of Derry-Londonderry_UK City of Culture 2013. City 18(4-5): 488496.

Dozens of Men and women march through Derry in paramilitary style The Irish News, 18th April 2017. http://www.irishnews.com/news/northernirelandnews/2017/04/18/news/dozens-ofmen-and-women-in-military-style-clothing-take-part-in-easter-rising-parade-through-derry999587/ accessed 30 April 2017.

Espiu Idoiaga, G. (2010) The Peace Processes in the Basque Country and Northern Ireland: A Comparative Approach 1994-2006. ICIP Working Papers. Institut Català Internacional per la $\mathrm{Pau}$ http://icip.gencat.cat/web/.content/continguts/publicacions/workingpapers/arxius/wp10_3 an g.pdf accessed $20^{\text {th }}$ October 2018 .

Frampton M (2012) Dissident Irish Republican Violence: A Resurgent Threat? The Political Quarterly 83(2): 227-237.

Galtung J (1967) Theories of Peace: A Synthetic Approach to Peace Thinking. Olso: International Peace Research Institute. 
Gonzalez S (2011) Bilbao and Barcelona 'in Motion'. How Urban Regeneration 'Models' Travel and Mutate in the Global Flows of Policy Tourism. Urban Studies 48(7): 1397-1418.

Graham B and McDowell S (2007) Meaning in the Maze: the heritage of Long Kesh. Cultural Geographies 14(3): 343-368.

Grewal B (2003) Johan Galtung: Positive and Negative Peace. Auckland: School of Social Science, Auckland University of Technology.

Hanauer DI (2011) The discursive construction of the separation wall at Abu Dis: Graffiti as political discourse. Journal of Language and Politics 10(3): 301-321.

Hocking, B. T. (2015). The Great Reimagining: Public Art, Urban Space, and the Symbolic Landscapes of $a^{\prime} \mathrm{New}^{\prime}$ Northern Ireland (Vol. 4). Berghahn Books.Jack EP (2015) From Belfast to Bilbao: The Basque Experience with the Irish Model. WORKING PAPERS IN CONFLICT TRANSFORMATION AND SOCIAL JUSTICE (6).

Johnsen CG and Sorensen BM (2015) 'It's capitalism on coke!': From temporary to permanent liminality in organization studies. Culture and Organization 21: 321-337.

Kan K (2001) Adolescents and Graffiti. Art Education 54(1): 18-23.

Kaufman S, Elliott M and Shmueli D (2003) Frames, framing and reframing. Beyond intractability, https://www.beyondintractability.org/essay/framing accessed 13 October 2017.

Koopman S (2011) Let's take peace to pieces. Political Geography 30: 193-94.

Koopman S (2017) Peace. The International Encyclopedia of Geography: 1-4.

Mitchel A and Kelly L (2011) Peaceful spaces? "Walking" through the new liminal spaces of peacebuilding and development in north Belfast. Alternatives 36(4): 307-325.

Loyd J M (2012) Geographies of peace and antiviolence. Geography Compass, 6(8): 477489. 
Matthews H (2007) The street as a liminal space. In Children in the city: Home, neighborhood and community. London: Routledge, pp. 101-117.

McConnell F, Megoran N and Williams P eds. (2014) Geographies of Peace. London: Tauris.

Megoran N (2011) War and peace? An agenda for peace research and practice in geography.

Political Geography 30: 178-89.

Moran D (2013) Between outside and inside? Prison visiting rooms as liminal carceral Spaces. GeoJournal, 78: 339-351.

Muro D (2005) Nationalism and nostalgia: the case of radical Basque nationalism. Nations and Nationalism 11(4): 571-589.

Murphy J., McDowell S, Braniff M and Denyer D (2017) Managing contested spaces: Public managers, obscured mechanisms and the legacy of the past in Northern Ireland. Environment and Planning C: Politics and Space 33(5): 919-934.

Murtagh B (1999) Listening to Communities: Locality Research and Planning. Urban Studies 36: 1181-1193.

Neill WJ (2006) Return to Titanic and Lost in the Maze: The search for Representation of 'Postconflict' Belfast. Space and Polity 10 (2): pp.109-120.

O'Neill L (2007) Fear of clashes at Apprentice Boys March https://www.belfasttelegraph.co.uk/news/northern-ireland/fear-of-clashes-at-apprentice-boysparade-as-republican-group-holds-protest-in-derry-36021046.html accessed 13 October 2017.

Prince S and Warner G (2012) Belfast and Derry in Revolt: A New History of the Start of the Troubles. Dublin: Irish Academic Press. 
Purdekova A (2017) Respacing for Peace? Resistance to Integration and the Ontopolitics of Rural Planning in Post-War Burundi. Development and Change 48(3): 534-566.

Rice P (2013) Personal Interview. Interviewed by Eileen Jack [in person] Belfast, 4 November cited in Jack, E. P. (2015). "From Belfast to Bilbao: The Basque Experience with the Irish Model. "WORKING PAPERS IN CONFLICT TRANSFORMATION AND SOCIAL JUSTICE (6).

Richmond O (2014) Foreword. In: McConnell F, Megoran N and Williams P (eds) Geographies of peace. London: IB Tauris, , pp xiv-xvii.

Ross A (2011) Geographies of war and the putative peace. Political Geography 30(4): 197199.

Rybczynski W (2002) 'The Bilbao effect' published in 'The Atlantic' September 2002. https://www.theatlantic.com/magazine/archive/2002/09/the-bilbao-effect/302582/ accessed 17 October 2017.

Sanchez-CuencaI (2007). The dynamics of nationalist terrorism: ETA and the IRA. Terrorism and Political Violence, 19(3), 289-306.

Saunders MNK and Townsend K (2016) Reporting and Justifying the Number of Interview Participants in Organization and Workplace Research. British Journal of Management 27 (4): 836-52.

Schirch L (2005) Ritual and Symbol in Peacebuilding. Kumarian Press.

Shirlow P (2008) Belfast: A Segregated City. in C Coulter \& M Murray (eds), Northern Ireland After the Troubles. Manchester University Press, pp. 73-87.

Soderlund J and Borg E (2017) Liminality in Management and Organization Studies:Process, Position and Place. International Journal of Management Reviews, n/a-n/a. 
Svorenčík A and Maas H (2015) The Making of Experimental Economics: Witness

Seminar on the Emergence of a Field. Springer International Publishing.

Szakolczai, A (2000) Reflexive Historical Sociology. London: Routledge.

Szakolczai A (2009) Liminality and experience: structuring transitory situations and transformative events. International Political Anthropology 2: 141-172.

The Executive Office (2015) Ilex Regeneration Committee Final Report https://www.executiveoffice-ni.gov.uk/regeneration

Thomassen B (2012) Anthropology and its many modernities: when concepts matter.

Journal of the Royal Anthropological Institute, 18: 160-178.

Thomassen B (2014) Liminality and the Modern: Living Through the In-between. London: Routledge.

Tonge J (2012) 'No-one likes us; we don't care': 'Dissident' Irish Republicans and Mandates. The Political Quarterly 83(2): 219-226.

Turner VW (1967) Betwixt and between: The liminal period in Rites de passage. In: Turner (ed) The forest of symbols: Aspects of Ndembu ritual. Ithaca, NY: Cornell UP, pp 93-111.

Vicario L and Monje J (2003) Another 'Guggenheim Effect'? The Generation of a Potentially Gentrifiable Neighbourhood in Bilbao. Urban Studies 40: 2383-2400.

Waldner LK and Dobratz BA (2013) Graffiti as a Form of Contentious Political Participation. Sociology Compass 7: 377-389.

Weizman E (2007) Hollow Land: Israel's Architecture of Occupation. London: Verso.

Williams P and McConnell F (2011) Critical Geographies of Peace. Antipode 43: 927-931.

Woodworth P (2001) The Basque Conflict \& Ireland. History Ireland 9(3): 41-47. 
